\title{
Flexibility Grave - Partial Reproduction Focus and Closed System Fetishism in CJEU, Pelham
}

\author{
Martin Senftleben
}

Published online: 8 May 2020

(C) The Author(s) 2020

\begin{abstract}
In the ongoing discussion about the impact of fundamental rights on EU copyright law, the Pelham judgment of the Court of Justice of the European Union (CJEU) has received much attention. However, the decision also raises important legal-doctrinal issues. The CJEU employs the harmonized right of reproduction as a vehicle to regulate adaptations of pre-existing source material. Moreover, the Court insists on a balancing of interests within the EU matrix of exclusive rights and limitations. The closed list of limitations in EU copyright law, however, can hardly be expected to offer sufficient breathing space for adaptation scenarios. As the Information Society Directive did not harmonize the right of adaptation, there was no need to include indispensable free adaptation rules that have evolved at the national level, such as the German "free use" doctrine. Instead of embracing national rules of equity and fairness to fill the gap, the CJEU is reluctant to borrow from the legal traditions of EU Member States and misses an important opportunity to provide guidance for the regulation of adaptations outside the sound sampling arena. After an introduction to the German "Metall auf Metall" saga that led to the Pelham decision, the following analysis sheds light on these developments in EU copyright law and discusses problems arising from the approach taken by the CJEU.
\end{abstract}

Keywords Sound sampling · Neighbouring right of phonogram producer . Adaptation and partial reproduction - Limitations and exceptions · Impact of fundamental rights $\cdot$ Freedom of the arts

\footnotetext{
Martin Senftleben is Professor of Intellectual Property Law at the Institute for Information Law (IViR), University of Amsterdam, The Netherlands; and Visiting Professor at the Intellectual Property Research Institute, University of Xiamen, China.

M. Senftleben $(\bowtie)$

Ph.D, Professor of Intellectual Property Law, Institute for Information Law (IViR), University of Amsterdam, Amsterdam, The Netherlands

e-mail: m.r.f.senftleben@uva.nl
} 


\section{Introduction}

With the CJEU judgment in Pelham, the German "Metall auf Metall" saga has reached another climax after no less than four decisions of the highest German courts. ${ }^{1}$ One may be tempted to say that, on the merits, the decisions revolve around a bagatelle: a rhythmic sequence of two seconds taken from "Metall auf Metall": a piece of electronic music that was part of the album "Trans Europa Express" which the iconic music group Kraftwerk released in 1977. The plaintiffs, Ralf Hütter and Florian Schneider-Esleben, formed the band in 1970. As pioneers in the field of electronical music, Kraftwerk has paved the way for music movements, such as electropop and techno. ${ }^{2}$

The defendants, Moses Pelham and Martin Haas, are the composers of "Nur mir": a song that was part of the 1997 album "Die neue S-Klasse" of the famous German rapper Sabrina Setlur. ${ }^{3}$ Pelham and Haas sampled the rhythmic sequence and used that sample in a continuous loop. Even though the copied sequence may appear small in terms of size, the market for music samples and their importance for musical genres, such as hip hop, certainly are not. ${ }^{4}$ It is therefore not surprising that the "Metall auf Metall" lawsuit has received much attention, both from an economic and an artistic point of view. ${ }^{5}$ The conflict between Kraftwerk and Pelham seemed to offer a good opportunity to clarify the impact of copyright and neighbouring rights on sound sampling.

\section{Préludes in Germany}

In its previous judgments, the German Federal Supreme Court failed to offer sufficient legal certainty for the assessment of sound sampling. Instead, the highest German court in civil law matters added nuances that increased the complexity of the legal analysis. ${ }^{6}$ In Metall auf Metall I, the Court took as a starting point that a phonogram producer could invoke his neighbouring right even if nothing more than a "tiny sound particle" had been copied.7 As the producer's organizational efforts related to the phonogram as a whole, the phonogram did not contain any part that was not the result of those efforts. ${ }^{8}$ Therefore, the Court deemed it necessary to

\footnotetext{
${ }^{1}$ German Federal Supreme Court (Bundesgerichtshof), 20 November 2008, case I ZR 112/06, Metall auf Metall, GRUR 2009, 403; German Federal Supreme Court, 13 December 2012, case I ZR 182/11, Metall auf Metall II, GRUR 2013, 614; German Federal Constitutional Court (Bundesverfassungsgericht), 31 May 2016, case 1 BvR 1585/13, Sampling, GRUR 2016, 690; German Federal Supreme Court, 1 June 2017, case I ZR 115/16, Metall auf Metall III, GRUR 2017, 895.

2 See https://nl.wikipedia.org/wiki/Kraftwerk (accessed 11 December 2019).

3 Cf. Podszun (2016), p. 606 (606).

4 Cf. Schipper (2014), p. 105 (105-106).

${ }^{5}$ For an overview of different dimensions of the lawsuit, see Podszun (2016), p. 606.

${ }^{6}$ Cf. Schipper (2014), p. 105 (108-109, 111).

7 German Federal Supreme Court, 20 November 2008, case I ZR 112/06, Metall auf Metall, GRUR 2009, 403, para. 14.
} 
make neighbouring rights protection available for every part of the phonogram, regardless of its size. ${ }^{9}$

The German Federal Supreme Court realized that a neighbouring right with these proportions, covering even the tiniest sound fragments, could endanger the freedom of musical expression. It therefore held that the German doctrine of "freie Benutzung" ("free use") - an exemption of adaptations that can be qualified as independent creations ${ }^{10}$ - could be applied by analogy to protected phonograms to enable cultural follow-on innovation on the basis of sound sampling. ${ }^{11}$ In light of the overarching objective to protect investments in sound recordings, phonogram producers were entitled to an exclusive right with a broader scope than copyright an exclusive right that covers sound fragments even if they do not meet the originality test. ${ }^{12}$ As a counterbalance, the Court declared the German doctrine of "freie Benutzung" applicable mutatis mutandis. As authors were bound to tolerate takings from their works that could be qualified as permissible free use, it was reasonable to expect the same from producers of phonograms. ${ }^{13}$

The German doctrine of "freie Benutzung" involves a comparison between the creative input that is present in an original work and the creative input that the secondary author added to a derivative work. ${ }^{14}$ This starting point can hardly be deemed exotic. In adaptation scenarios, it is not unusual to embark on an assessment of the degree of originality of the prior work on the one hand, and the degree of originality of the derivative work on the other. In several EU Member States, the infringement analysis is configured in this way when copyrighted source material is incorporated in a new literary and artistic creation that has original features of its own. In the Netherlands, the courts use a similar starting point to determine whether an adaptation is a new, independent creation. ${ }^{15}$ Like German copyright law, the Austrian Copyright Act contains an exemption of "freie Benutzung". ${ }^{16}$ In Swedish Scapegoats, the Supreme Court of Sweden asked whether the derivative work was characterized by the secondary author's individuality and possessed such a degree of originality that there was a new creation with independent copyright protection. ${ }^{17}$

\footnotetext{
9 German Federal Supreme Court, 20 November 2008, case I ZR 112/06, Metall auf Metall, GRUR 2009, 403, para. 14

10 See Sec. 24(1) of the German Copyright Act: "An independent work created in the free use of the work of another person may be published and exploited without the consent of the author of the work used." Cf. Dreier and Schulze (2018), pp. 454-457; Bently, Dusollier and Geiger et al. (2019), p. 467 (486-487); Hugenholtz and Senftleben (2011), pp. 26-27; Geller (2010), p. 901 (901).

11 German Federal Supreme Court, 20 November 2008, case I ZR 112/06, Metall auf Metall, GRUR 2009, 403, para. 21.

12 German Federal Supreme Court, ibid., para. 16.

13 German Federal Supreme Court, ibid., para. 21.

14 German Federal Supreme Court, ibid., para. 25. Cf. Dreier and Schulze (2018), p. 454.

15 Supreme Court of the Netherlands (Hoge Raad), 5 January 1979, Nederlandse Jurisprudentie 1979, No. 339, Hollebrand/Heertje. Cf. Spoor, Verkade and Visser (2019), pp. 181-188.

16 Sec. 5(2) Austrian Copyright Act. Cf. Supreme Court of Austria (Oberster Gerichtshof), 13 July 2010, case 4 Ob 66/10z, Lieblingshauptfrau. See also CJEU, 1 December 2011, case C-145/10, Painer, paras. 41-42, where the Austrian doctrine of "freie Benutzung" is mentioned.

17 Supreme Court of Sweden (Högsta Domstolen), 21 February 2017, case T 1963-15, Swedish Scapegoats, GRUR Int. 2019, 93, para. 12.
} 
The Court deemed it decisive whether the work used as a model had been transformed to such an extent that a new and independent work had been created. ${ }^{18}$ The analysis led to the result that - despite copying from a pre-existing photographic work - the painting at issue did not amount to copyright infringement: "Overall, in such a transformation of the photographic work, M[arkus] A[ndersson] has achieved a new and independent work of art that expresses his individuality. Therefore, MA's use of his artwork does not infringe J[onas] L[emberg]'s copyright in the photographic work." 19

In Italy, the case Big Red/Gabibbo shed light on the possibility that later, different expressions of an idea underlying a pre-existing work - new creativity that adds individualizing, specific and distinctive traits to a derivative work - could be deemed permissible and escape the verdict of infringement. The Supreme Court of Italy clarified the limits of this free adaptation rule by explaining that a permissible, independent derivative work had to be distinguished from cases of "evolutionary plagiarism" that did not generate an original and individual work that was merely inspired by a pre-existing creation, but constituted an abusive and unauthorized elaboration of the prior work. ${ }^{20}$

Considering these examples, the exemption of certain types of derivative works, namely adaptations that reflect a high degree of new, fresh originality, can be regarded as a feature of the copyright traditions of many EU Member States. The German doctrine of "freie Benutzung" is a specific manifestation of this broader legal tradition. It requires an adaptation to be "independent" in the sense that it achieves a sufficient distance from protected parts of the original work that have been taken over. ${ }^{21}$ According to the case law of the German Federal Supreme Court, this scenario arises when the derivative work has new original features of its own that make the individual features of the incorporated, copyrighted source material fade away. ${ }^{22}$

From a German perspective, it was thus consistent to rely on the doctrine of "freie Benutzung" to regulate sound sampling. The resulting configuration of the infringement analysis offered a promising balance: a broad neighbouring right on the one hand; room for "freie Benutzung" as a counterweight on the other. However, the German Federal Supreme Court added that the defence of "freie Benutzung" was inapplicable if the producer of the derivative musical work could produce the required sound material herself. ${ }^{23}$ The Court found that in this situation, the right of the producer of the pre-existing phonogram did not pose an obstacle to

\footnotetext{
${ }_{18}$ Supreme Court of Sweden, ibid., para. 12.

${ }^{19}$ Supreme Court of Sweden, ibid., paras. 18-19.

${ }^{20}$ Supreme Court of Italy (Corte di Cassazione), 6 June 2018, case 14635/2018, Big Red/Gabibbo, GRUR Int. 2019, 413 (415), para. 4.2.1.

${ }^{21}$ German Federal Supreme Court, 20 November 2008, case I ZR 112/06, Metall auf Metall, GRUR 2009, 403, para. 25.

${ }^{22}$ German Federal Supreme Court, ibid., para. 25. See also German Federal Supreme Court, 16 April 2015, case I ZR 225/12, Goldrapper, GRUR 2015, 1189 (1198); German Federal Supreme Court, 1 December 2010, case I ZR 12/08, Perlentaucher, GRUR 2011, 134 (137-138); German Federal Supreme Court, 20 March 2003, case I ZR 117/00, Gies-Adler, GRUR 2003, 956 (958).
}

${ }^{23}$ Cf. Schipper (2019), p. 162 (162-163). 
cultural follow-on innovation. Hence, it was no longer justified to impose the obligation on the phonogram producer to tolerate unauthorized sound sampling. ${ }^{24}$ In Metall auf Metall II, the Court refined this assessment standard by clarifying that a permissible "freie Benutzung" of sound samples was excluded if, at the time when the unauthorized use took place, a music producer with average equipment and skills would have been able to create a recording herself which the target audience would have regarded as equivalent sound material for use in the same musical context. $^{25}$

With this refinement, the German Federal Supreme Court added a complicating factor to the infringement analysis that could hardly pass the litmus test of application in practice. What is average equipment and what are average skills in the field of music production? When is self-produced sound material equivalent to the sample taken from a pre-existing recording? What investment of time and money should be expected from the music producer? The legal uncertainty arising from these questions can easily thwart the invocation of "freie Benutzung" as a defence. Therefore, Pelham appealed to the German Federal Constitutional Court, the highest German court in matters relating to fundamental rights. According to Pelham, the complexity of the infringement analysis and the legal uncertainty following from the jurisprudence of the German Federal Supreme Court led to an erosion of the freedom of art. ${ }^{26}$ The German Federal Constitutional Court agreed. The legal risks resulting from the test of equivalent self-production which the German Federal Supreme Court had introduced could not be deemed acceptable in the light of the fundamental freedom of the arts. The legal uncertainty following from the application of this criterion would have a deterrent effect on artists seeking to use sound sampling to express themselves. The German Federal Constitutional Court feared that

even in cases where the production of an equal recording is not possible, artistic creators may refrain from use - which, in this case, would be permissible in the opinion of the German Federal Supreme Court - because the effort necessary to provide evidence of missing own production options and the legal risk appear too big. The criterion based on the feasibility of producing an equal sound thus has a deterrent effect which requires a particularly efficient control in the light of constitutional law. ${ }^{27}$

With regard to the taking from Kraftwerk's piece "Metall auf Metall", the German Federal Constitutional Court came to the conclusion that, considering the limited size of the copied rhythmic sequence, Kraftwerk was only confronted with a small impairment of its phonogram producer rights which did not involve

\footnotetext{
${ }^{24}$ German Federal Supreme Court, 20 November 2008, case I ZR 112/06, Metall auf Metall, GRUR 2009, 403, para. 23.

25 German Federal Supreme Court, 13 December 2012, case I ZR 182/11, Metall auf Metall II, GRUR 2013, 614, para. 40.

26 German Federal Constitutional Court, 31 May 2016, case 1 BvR 1585/13, Sampling, GRUR 2016, 690, paras. 25-31.

27 German Federal Constitutional Court, ibid., para. 100.
} 
substantial economic disadvantages. The inroads into freedom of the arts, by contrast, were considerable. Weighing Kraftwerk's intellectual property rights against Pelham's concerns about an erosion of sound sampling as an art form, the Court arrived at the conclusion that the small impairment of phonogram producer rights could not justify the substantial encroachment upon the freedom of art. ${ }^{28}$ According to the German Federal Constitutional Court, the prerequisite of equivalent self-production was not suitable to ensure an appropriate balance between freedom of artistic expression and the protection of the phonogram producer's intellectual property right. ${ }^{29}$ To strike a proper balance between the fundamental rights involved, it was necessary to introduce a different criterion that would offer more room for applying the doctrine of "freie Benutzung" by analogy. ${ }^{30}$ Alternatively, the German Federal Supreme Court could interpret the phonogram producer's neighbouring right more restrictively and preclude the assertion of this right from the outset. In any case, an infringement claim should only succeed if unauthorized sound sampling jeopardizes the phonogram producer's economic interests to a considerable extent. ${ }^{31}$

Furthermore, the German Federal Constitutional Court paved the way for the prejudicial questions which the CJEU answered in Pelham. The German Federal Constitutional Court pointed out that the fundamental rights laid down in the Charter of the European Union were decisive for the interpretation of German laws following from the implementation of EU law. ${ }^{32}$ The fundamental rights laid down in the German Basic Law (Grundgesetz) were only applicable in areas where European legislation did not aim at maximum harmonization and left room for national law and policy-making. ${ }^{33}$ Against this background, the Court raised the issue of the extent to which the 2001 Information Society Directive (ISD) ${ }^{34}-$ the European basis for the phonogram producer's neighbouring right invoked by Kraftwerk - determined German legislation. Remanding the case, the Court explicitly posed the questions whether the sound sampling amounted to a relevant reproduction in the sense of the harmonized concept underlying the Information Society Directive, whether CJEU decisions addressing the reproduction right were applicable to the neighbouring right of the phonogram producer, and whether EU law regulated limitations of protection in an exhaustive manner. ${ }^{35}$ The Court added that prejudicial questions were necessary to ensure the effective enforcement of the fundamental rights guaranteed in the EU Charter. ${ }^{36}$ Given these clear instructions, it

\footnotetext{
${ }^{28}$ German Federal Constitutional Court, ibid., para. 107.

${ }^{29}$ German Federal Constitutional Court, ibid., paras. 107-108. Cf. Podszun (2016), p. 606 (610-611).

${ }^{30}$ German Federal Constitutional Court, ibid., para. 110.

${ }^{31}$ German Federal Constitutional Court, ibid., para. 110.

${ }^{32}$ German Federal Constitutional Court, ibid., para. 115.

${ }^{33}$ German Federal Constitutional Court, ibid., para. 117.

${ }^{34}$ Directive 2001/29/EC of the European Parliament and of the Council of 22 May 2001, on the harmonisation of certain aspects of copyright and related rights in the information society, OJ 2001 L 167, 10.

${ }^{35}$ German Federal Constitutional Court, 31 May 2016, case 1 BvR 1585/13, Sampling, GRUR 2016, 690, para. 118.
} 
did not come as a surprise that the German Federal Supreme Court asked the prejudicial questions which ultimately led to the Pelham decision of the CJEU. ${ }^{37}$

\section{Toccata at EU Level}

Dealing with the questions following from the German decisions, the CJEU dismissed the complicated infringement test which the German Federal Supreme Court had developed. The CJEU held that while it was correct to assume that the exclusive right laid down in Art. 2(c) ISD enabled the phonogram producer to prohibit the unauthorized reproduction of sound samples even if very short, this did not apply when the sound fragment taken from the original phonogram was used in a derivative phonogram "in a modified form unrecognisable to the ear". ${ }^{38}$ Thus, it was correct to assume that broad protection was the rule. Even the taking of "tiny sound particles", as the German Federal Supreme Court called it, ${ }^{39}$ amounts to infringement. ${ }^{40}$ However, the sampling artist can escape the verdict of infringement by integrating sampled source material in a way that renders it unidentifiable for the ear.

Undoubtedly, the criterion of "unrecognisable to the ear" ${ }^{41}$ will give rise to controversies as well. ${ }^{42}$ Which ear to be exact? ${ }^{43}$ The ear of the sampling specialist with long working experience in the hip hop sector who is able to dissect every song and identify a large number of individual building blocks derived from the existing musical repertoire? Or the ear of the average music consumer who is not listening to hip hop in an analytical way and does not actively search for sound particles taken from other music productions? In light of the necessity to offer sufficient room for freedom of artistic expression, it seems preferable to adhere to the latter approach: the average music consumer should constitute the relevant reference point for the assessment. $^{44}$

Despite these remaining uncertainties, however, the CJEU has developed an infringement test that seems easier to apply than the complex criterion of equivalent self-production that resulted from the jurisprudence of the German Federal Supreme Court. $^{45}$ There is a further positive aspect that should be mentioned. The extension of the scope of the right of the phonogram producer to sound particles "even if very

\footnotetext{
37 German Federal Supreme Court, 1 June 2017, case I ZR 115/16, Metall auf Metall III, GRUR 2017, 895, dictum.

38 CJEU, 29 July 2019, case C-476/17, Pelham, paras. 29-31.

39 German Federal Supreme Court, 20 November 2008, case I ZR 112/06, Metall auf Metall, GRUR 2009, 403, para. 14.

${ }^{40}$ With this judgment, the CJEU rejects more flexible tests, such as an assessment on the basis of the question whether the adopted part entails a "substantial part" of the phonogram. $C f$. in this context Ohly (2017), p. 964 (966-967).

41 CJEU, 29 July 2019, case C-476/17, Pelham, paras. 29-31.

42 Kulk and Teunissen (2019b), p. 149 (155).

43 Schipper (2019), p. 162 (164).

44 See also in this context Leistner (2019), p. 1008 (1010).

45 Cf. Schipper (2019), p. 162 (166).
} 
short" 46 particularly threatens so-called "collage sampling" - the integration of a large number of (often very small) sound fragments in a new phonogram. ${ }^{47}$ In practice, this specific method of sampling will barely have a chance to survive if the sampling artist is forced to acquire licences for each and every individual sound particle. The large number of required licences will cause prohibitively high transaction and licensing costs. Collage sampling productions are thus unlikely to happen in the first place and, if they occur, unlikely to reach the market. ${ }^{48} \mathrm{~A}$ broad neighbouring right for phonogram producers may thus exterminate a whole branch of sampling that may be particularly important from a cultural point of view. ${ }^{49}$ In this regard, the legal framework established by the CJEU may offer relief. The complexity of sound mosaics arising from collage sampling may lead to a situation where individual building blocks remain unrecognizable to the ear and satisfy the exemption criterion introduced by the CJEU. ${ }^{50}$

\subsection{Regulation of Adaptation Scenarios}

The price to be paid for this breathing space for collage sampling, however, is high. The CJEU's formula - "sound sample [...] in a modified form unrecognisable to the ear" - reveals that the highest EU court does not hesitate to regulate adaptations of protected subject matter through the backdoor of the harmonized right of reproduction. ${ }^{51}$ In the field of the neighbouring right of phonogram producers, this development does not clearly come to the fore because neither international nor EU law provides for a right of adaptation. With regard to copyright, however, the Berne Convention (BC) draws a distinction between the right of reproduction on the one hand (Art. $9 \mathrm{BC}$ ) and the right of adaptation on the other (Arts. 8, 12 and 14 BC) ${ }^{52}$ Against this background, the CJEU could have been more cautious. The "Metall auf Metall" lawsuit clearly concerned an adaptation scenario. The Court could thus have declared that there was no maximum harmonization and that questions relating to adaptations should be answered at the national level.

The CJEU, however, preferred a different approach: every adaptation that involves an act of partial reproduction is subject to the right of reproduction in Art. 2(c) ISD. ${ }^{53}$ The far-reaching consequences of this approach clearly come to light when taking into consideration the CJEU's further decision that a sound sample falls within the scope of the phonogram producer's neighbouring right "even if very short." ${ }^{, 54}$ It follows that every taking of sound snippets - no matter how small -

\footnotetext{
46 CJEU, 29 July 2019, case C-476/17, Pelham, para. 29.

47 See Morrison (2008), p. 75 (96), for a discussion on the different forms of sampling.

48 Schipper (2014), p. 105 (111).

49 Podszun (2016), p. 606 (608); Duhanic (2016), p. 1007 (1009-1010).

50 Leistner (2019), p. 1008 (1014).

51 CJEU, 29 July 2019, case C-476/17, Pelham, para. 29.

52 See Ricketson and Ginsburg (2006), paras. 11.35-11.37, for a discussion of the various national traditions and interpretations regarding the Berne Convention.

53 CJEU, 29 July 2019, case C-476/17, Pelham, para. 29.

54 CJEU, ibid., para. 29.
} 
amounts to a relevant partial reproduction. Hence it seems that after Pelham there are no adaptations of sounds recordings that could fall outside the scope of the harmonized right of reproduction. ${ }^{55}$ Therefore, the CJEU puts an end to the flexibility that EU Member States traditionally enjoyed in the area of the right of adaptation.

This outcome leads to a problematic shift of perspective. As explained above, adaptations have been assessed traditionally in many EU Member States in the light of the ratio between the originality taken from pre-existing sources and the own creative input of the secondary creator. ${ }^{56}$ Following this approach, it is conceivable that new original aspects of the adaptation overshadow original elements of preexisting source material to such an extent that infringement can no longer be found. However, this dynamic approach can hardly survive under the static focus on partial reproduction which the CJEU must adopt in the absence of harmonized adaptation rules. In consequence, the identification of a protected trace of third-party content in a derivative literary and artistic production will inevitably culminate in a finding of infringement of the right of (partial) reproduction.

Admittedly, the CJEU does not dare to defend this extreme protection automatism. To ensure a fair balance between the fundamental interests of copyright and neighbouring right holders on the one hand, and the freedom of expression of users of protected source material on the other, ${ }^{57}$ the Court departs from an absolute protection paradigm. ${ }^{58}$ The intellectual property rights of authors and phonogram producers must be weighed against other fundamental rights, such as the freedom of artistic expression ${ }^{59}$ which includes sound sampling as a "form of artistic expression". ${ }^{60}$ Stating that unrecognizable sound samples may be used freely, the CJEU seeks to establish an appropriate equilibrium. ${ }^{61}$ After all, these sound samples "would not interfere with the opportunity which the producer has of realising satisfactory returns on his or her investment". 62

As mentioned, the criterion of unrecognizability is good news for activities in the field of collage sampling. It is also possible to draw a parallel between the CJEU judgment and the decision of the German Federal Constitutional Court which pointed to the disproportionate relationship between a small impairment of the right of the phonogram producer and considerable inroads into artistic follow-on innovation. ${ }^{63}$ Nonetheless, the CJEU formula is incapable of emulating the traditional dynamic assessment in the area of adaptations: the weighing of the degree of originality of the derivate creation against the degree of originality of

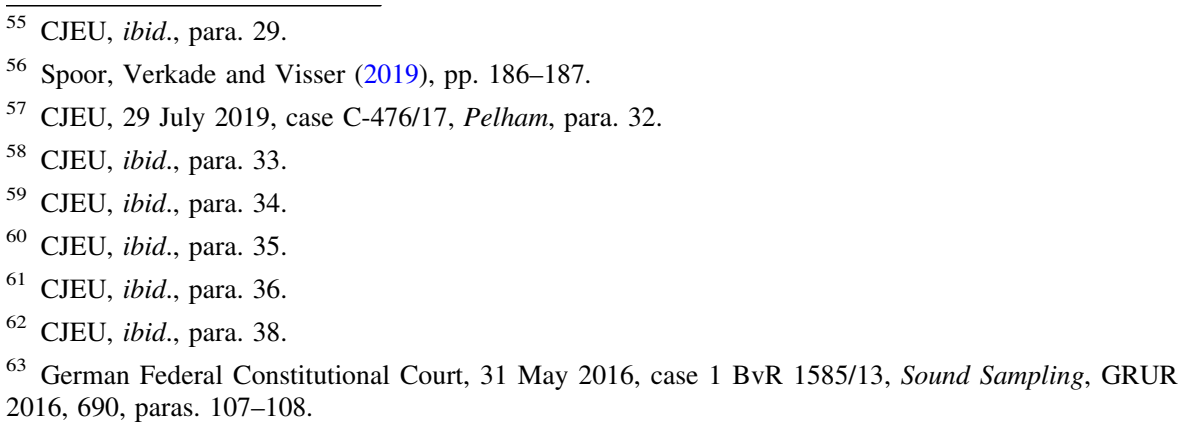


source material taken from pre-existing sources. In this respect, the Pelham decision is wanting. Instead of focussing on each and every snippet deduced from a preexisting sound recording, the CJEU could have integrated the German doctrine of "freie Benutzung" into harmonized EU law. Why not conclude that the phonogram producer can prohibit the reproduction of unauthorized sound samples - "even if very short" 64 - unless the original features of pre-existing sources fade away in the light of new original elements added by the sampling artist? ${ }^{65}$

\subsection{Rejection of "freie Benutzung"}

Instead, the CJEU rejected the German doctrine of "freie Benutzung" altogether - a missed opportunity to develop EU law in the light of the legal traditions of EU Member States. As indicated above, the doctrine of "freie Benutzung" plays an important role not only in German but also in Austrian copyright law. ${ }^{66}$ Moreover, similar rules on the relationship between elements taken from pre-existing works and self-created elements of new literary and artistic productions have evolved in other Member States. ${ }^{67}$ In essence, Sec. 24(1) of the German Copyright Act - the national basis of the right of "freie Benutzung" - requires an assessment of whether a derivative production keeps a sufficient distance from embedded source material to justify its qualification as an "independent work". Dutch copyright law, for instance, also exempts adaptations that constitute "a new and original work". 68 Against the backdrop of this configuration of national copyright laws in the EU, the German Federal Supreme Court rightly pointed out that the doctrine of "freie Benutzung" did not constitute a derogation from copyright but rather an inherent limitation of its scope of protection, based on the idea that it was not possible to conceive of a cultural creation without that creation building upon the previous work of other authors. ${ }^{69}$

The CJEU, however, did not make any distinction between inherent borders of exclusive rights (a certain form of use is regarded to fall outside the scope of the exclusive right from the outset) and the limitations laid down in Art. 5 ISD (a certain form of use is regarded to fall within the scope of the exclusive right, but is nevertheless justified because the user can invoke a valid defence argument). Instead, the CJEU forced the German doctrine of "freie Benutzung" into the straitjacket of the closed list of permissible limitations in Art. 5 ISD. ${ }^{70}$ In this

\footnotetext{
${ }^{64}$ CJEU, 29 July 2019, case C-476/17, Pelham, para. 29.

${ }^{65}$ See the application of this assessment standard in German Federal Supreme Court, 16 April 2015, case I ZR 225/12, Goldrapper, GRUR 2015, 1189 (1198); German Federal Supreme Court, 1 December 2010, case I ZR 12/08, Perlentaucher, GRUR 2011, 134 (137-138); German Federal Supreme Court, 20 March 2003, case I ZR 117/00, Gies-Adler, GRUR 2003, 956 (958).

${ }^{66}$ Cf. Supreme Court of Austria, 13 July 2010, case 4 Ob 66/10z, Lieblingshauptfrau.

${ }^{67}$ Supreme Court of Sweden, 21 February 2017, case T 1963-15, Swedish Scapegoats, GRUR Int. 2019, 93, paras. 12, 17-19; Supreme Court of Italy, 6 June 2018, case 14635/2018, Big Red/Gabibbo, GRUR Int. 2019, 413 (415). Cf. Bently, Dusollier, Geiger et al. (2019), p. 486.

${ }^{68}$ Cf. Schipper (2014), p. 105 (108-109).

${ }^{69}$ CJEU, 29 July 2019, case C-476/17, Pelham, para. 56.

${ }^{70}$ Cf. Leistner (2019), p. 1008 (1011).
} 
context, the Court ignored the fact that, as the Information Society Directive did not harmonize the right of adaptation, the closed list of copyright limitations in Art. 5 ISD has never been intended to serve as a reference point for regulating the relationship between takings of original elements from pre-existing works and new originality that the secondary author added during the adaptation process.

The erosion of the difference between inherent borders of exclusive rights and statutory limitations of the scope of protection goes hand in hand with unlimited faith in the legal framework set forth in EU copyright law. It follows from the Pelham decision that a fair balance between the intellectual property rights of authors and neighbouring rights holders, and competing fundamental rights of users, such as freedom of artistic expression, must be found within the system of exclusive rights and limitations of the Information Society Directive. ${ }^{71}$ The CJEU insists on an internal balancing of interests. The Court seems convinced that EU copyright law offers sufficient room for the freedom of art and other fundamental rights of users, such as freedom of expression, freedom of information and freedom of science. ${ }^{72}$ In the Court's opinion, even the three-step test in Art. 5(5) ISD helps to maintain an appropriate balance. ${ }^{73}$ The CJEU is thus reluctant to enrich the harmonized copyright system with external correction mechanisms that are available in EU law, such as the direct invocation of fundamental rights in the Charter as additional safeguards against excessive copyright protection. ${ }^{74}$ All of this is necessary to achieve the harmonization goals of the Information Society Directive and prevent disruptions of the internal market. ${ }^{75}$ Hence, the German doctrine of "freie Benutzung" cannot survive. As the closed list of Art. 5 ISD does not contain a free adaptation rule, such as the German rule of "freie Benutzung", it inhibits national lawmakers and judges from recognizing and maintaining this inherent limitation of the scope of exclusive rights. ${ }^{76}$

\subsection{Impact on Copyright Law}

Discussing this point, it must not be overlooked that the Pelham judgment concerns the neighbouring right of phonogram producers. This raises the question of which repercussions the CJEU ruling may have on copyright law. As to the focus on internal balancing, the answer seems quite clear. The CJEU has expressed its preference for reconciling competing fundamental rights within the EU copyright

\footnotetext{
71 CJEU, 29 July 2019, case C-476/17, Pelham, para. 60.

72 With regard to the freedom of science, see District Court of Amsterdam, 23 December 2015, ECLI:NL:RBAMS:2015:9312, Anne Frank-Fonds/Anne Frank Stichting and KNAW, Intellectuele eigendom en reclamerecht 2017/5, r.o. 4.8.3. See also European Court of Human Rights, 10 January 2013, case 36769/08, Ashby Donald/Frankrijk, para. 38; and Geiger and Izyumenko (2014), p. 316, regarding the need to offer room for freedom of expression and freedom of information.

73 CJEU, 29 July 2019, case C-476/17, Pelham, para. 62.

74 Leistner (2019), p. 1008 (1012). For a discussion of the various forms of internal and external balancing, see Kulk and Teunissen (2019a), p. 121 (126-129); Geiger and Izyumenko (2014), p. 316; Dreier (2001), p. 295.

75 CJEU, 29 July 2019, case C-476/17, Pelham, para. 63.

76 CJEU, ibid., para. 65.
} 
framework of exclusive rights and limitations in such broad terms that the focus on internal balancing is likely to prevail over the use of fundamental rights as external correction mechanisms in a copyright context as well. The focus on the harmonized system of rights and limitations and the rejection of traditional national doctrines also corresponds to the route that the CJEU has chosen in trademark law. ${ }^{77}$

As for the harmonization of the right of adaptation, the CJEU has the choice between two points of reference. In $O S A$, the Court drew a distinction between the exclusive rights of authors "of a preventive nature" and the phonogram producer rights laid down in Art. 8(2) of Directive 92/100/EEC "of a compensatory nature". ${ }^{78}$ This distinction served as a basis for declaring the assessment criteria that were relevant in the neighbouring rights case Marco del Corso $^{79}$ irrelevant in a copyright context. ${ }^{80}$ However, this decision did not prevent the CJEU from following the opposite approach in Reha Training where it held that - despite the different nature of the rights - the term "communication to the public" had the same meaning in the context of copyright and neighbouring rights. ${ }^{81}$ As Reha Training is the more recent decision, this latter point of view (same meaning in a copyright and neighbouring rights context) is likely to inform decisions in the field of the right of reproduction. There is even more reason to expect this outcome when it is considered that Pelham does not concern the remuneration right of Art. 8(2) of Directive 92/100/EEC but the exclusive right which Art. 2 ISD bestows upon authors (sub a) and phonogram producers (sub c) alike. A priori, there is thus no difference in nature that could justify a distinction between authors' rights of a preventive nature and phonogram producers' rights of a compensatory nature. Hence, the CJEU can give the copyright concept of "partial reproduction" a meaning that corresponds to the approach taken in Pelham. This does not mean that reproducing elements of a literary and artistic work - no matter how small - will automatically lead to a finding of infringement. In Infopaq, the CJEU clarified that, for copying to amount to a relevant partial reproduction in a copyright context, it was necessary that copied elements fulfil the originality test. That could only be the case if these elements - analyzed in isolation - reflect a sufficient degree of free, creative choices to qualify as their author's "own intellectual creation". 82

Apart from this different threshold requirement, however, nothing seems to prevent the CJEU from following the same logic: if elements of a pre-existing work that enjoy copyright protection are incorporated in a derivative work, the integration of copyrighted source material, inevitably, leads to a finding of an infringing partial reproduction - regardless of new creative input that the secondary author may have added. Hence, the CJEU may harmonize the right of adaptation by applying a

\footnotetext{
77 CJEU, 19 September 2013, case C-661/11, Martin Y Paz Diffusion, paras. 54-55. Cf. Senftleben (2016), p. 327 (350-357); Kur (2014), p. 434 (450-453).

78 For a further discussion of this distinction, see CJEU, 15 March 2012, case C-135/10, SCF/Marco del Corso, para. 75, and the case comment by Visser (2013), p. 41 (46); Hugenholtz (2013), No. 197.

79 CJEU, 15 March 2012, case C-135/10, SCF/Marco del Corso, paras. 95-98.

${ }^{80}$ CJEU, 27 February 2014, case 351/12, OSA, para. 35.

81 CJEU, 31 May 2016, case C-117/15, Reha Training, paras. 33-34.

82 CJEU, 16 July 2009, case C-5/08, Infopaq/DDF, paras. 38-39.
} 
narrow concept of partial reproduction to derivative works. It may even be said that the CJEU has already paved the way for this development in its Painer and SAS Institute judgments. In both cases, adaptation scenarios played a role. In both decisions, the Court employed the concept of partial reproduction as a vehicle to answer the prejudicial questions. ${ }^{83}$ From this perspective, the Court's explicit reference to sound samples "in a modified form unrecognisable to the ear" 84 appears as a corollary of these earlier decisions. Even though the CJEU does not refer to its judgments in Painer and SAS Institute, it is likely that adaptation rules have been harmonized not only in the field of neighbouring rights, but in copyright law as well. As mentioned, the strategy which the CJEU follows for this purpose leads to a corrosive shift of perspective. In the absence of an adaptation right in the Information Society Directive, the Court is bound to focus on partial reproduction. Takings from pre-existing works are decisive. The own creative effort of the secondary author, by contrast, has hardly any chance of entering the picture.

\section{Lamento or Laudatio?}

Should we congratulate the CJEU on its Pelham judgment $?^{85}$ Or is the decision disastrous? As to flexibility in EU copyright law, the Pelham judgment can hardly be deemed good news. Adaptation scenarios must be analyzed through the prism of the harmonized right of reproduction. Inherent limits of exclusive rights that have been recognized in the legal traditions of EU Member States can only survive if they fall within the scope of the limitation prototypes in Art. 5 ISD. The reconciliation of the protection of copyright and neighbouring rights with competing user freedoms must occur within the harmonized system of exclusive rights and limitations in the Information Society Directive. Fundamental rights are not meant to be used as external correction mechanisms.

With one stroke of a brush, the CJEU has thus eliminated multiple sources of flexibility. ${ }^{86}$ This seems irresponsible in light of the known defects of the harmonized copyright matrix. An open-ended "fair use" clause that would allow timely reactions to new technologies, new forms of sharing information and new social, cultural and economic needs, is sought in vain in the EU copyright acquis. ${ }^{87}$ The three-step test in Art. 5(5) ISD can only be used to impose additional constraints on copyright limitations. In contrast to the international three-step test, ${ }^{88}$ the crippled EU offspring does not provide breathing space for the evolution of new

\footnotetext{
83 CJEU, 1 December 2011, case C-145/10, Painer, paras. 41-42, 95-99, and the case comment by van Eechoud (2011), p. 6. Cf. Ohly (2017), p. 964 (967). See also CJEU, 2 May 2012, case C-406/10, SAS Institute, paras. 67-70. Cf. Gervais and Derclaye (2012), p. 570; Griffiths (2014), p. 1106 (1107).

84 CJEU, 29 July 2019, case C-476/17, Pelham, para. 31.

85 For a positive assessment, see Leistner (2019), p. 1008 (1014).

86 For an overview, see Hugenholtz and Senftleben (2011), pp. 26-27.

87 Regarding the discussion on "fair use", see Senftleben (2013a), p. 30; Förster (2008), pp. 182-184; Cohen Jehoram (2005a), p. 153; Cohen Jehoram (2005b), p. 359; Cohen Jehoram (1998), p. 174; Alberdingk Thijm (1998a), p. 145; Alberdingk Thijm (1998b), p. 176; Hugenholtz (1989), pp. 170-171. 88 See the Agreed Statement on the three-step test in Art. 10 WCT. See also Senftleben (2010), p. 67.
} 
use privileges and the further development of existing limitations. The CJEU confirms this once again in Pelham. ${ }^{89}$

Despite all this, the final chord need not be entirely gloomy. The Court recognizes explicitly that freedom of the arts belongs to the circle of fundamental rights that impact the scope of copyright and neighbouring rights. ${ }^{90}$ The CJEU underlines the importance of safeguarding an appropriate balance between copyright protection on the one hand, and freedom of artistic expression and other fundamental rights of users on the other. ${ }^{91}$ The CJEU also seems determined to establish this balance within the harmonized framework of exclusive rights and limitations. $^{92}$ The decision reflects several balancing factors known from the freedom of expression analysis. ${ }^{93}$ Future judgments may therefore bring to light unprecedented fireworks of new sources of flexibility within EU copyright law.

However, the preview of new balancing tools in the Pelham judgment itself is not very promising. The Court is far from adopting an active role and exploring new avenues for supporting freedom of expression and freedom of the arts within the copyright system. The exemption of sound samples that remain unrecognizable to the ear does not go any further than the template which the German Federal Constitutional Court provided in its earlier decision in the "Metall auf Metall" saga. ${ }^{94}$ The CJEU seems unwilling to do more than what is absolutely necessary to ensure congruence with the earlier German fundamental rights decision. In this way, the Court can entertain a respectful dialogue with the highest German judges in constitutional matters. This tailor-made solution, however, is evidently based on the specific fact pattern in the area of sound sampling. A broader concept for ensuring sufficient deference to freedom of the arts and other fundamental rights is not discernible. The discussion of the right of quotation in Art. 5(3)(d) ISD confirms the impression that the Court prefers a very cautious approach. The CJEU states that for a quotation to be justified, it is necessary that a work be used "for the purposes of illustrating an assertion, of defending an opinion or of allowing an intellectual comparison between that work and the assertions of that user". 95

A user invoking the right of quotation must have the intention of "entering into 'dialogue' with that work". 96 According to the Court, this is possible in cases of sound sampling. ${ }^{97}$ The right of quotation may thus offer refuge to sampling artists using recognizable fragments of pre-existing sound recordings - if they manage to set up a dialogue. Nevertheless, the dialogue requirement reveals a conservative and

\footnotetext{
${ }^{89}$ CJEU, 29 July 2019, case C-476/17, Pelham, para. 64.

90 CJEU, ibid., paras. 32-35.

91 CJEU, ibid., paras. 32, 37, 59. As to the recognition of "user rights" flowing from the recognition of exceptions and limitations in copyright law, see Geiger and Izyumenko (2020), section 3.1.

92 CJEU, ibid., para. 60.

93 Cf. Geiger and Izyumenko (2020), section 3.1.

94 See CJEU, 29 July 2019, case C-476/17, Pelham, paras. 29-31 and 38, on the one hand, and German Federal Constitutional Court, 31 May 2016, case 1 BvR 1585/13, Sampling, GRUR 2016, 690, para. 107, on the other.

95 CJEU, ibid., para. 71.

96 CJEU, ibid., para. 71

97 CJEU, ibid., para. 72. Cf. Schipper (2019), p. 162 (165). See furthermore Ohly (2017), p. 964 (968-969), who argues that the "pastiche" exception (Art. 5(3)(k) ISD) is also applicable.
} 
inelastic conception of "quotation". ${ }^{98}$ Collages and appropriation art are impermissible, unless the secondary author comments upon integrated source material. The same applies to modern forms of references to copyrighted sources, such as the results of an image search. ${ }^{99}$ If this is the way in which the CJEU intends to maintain a fair balance in EU copyright law, tough times lie ahead.

An example of lost breathing space can already be found in Dutch copyright law. In line with Art. 5(3)(d) ISD, the right of quotation in Art. 15a of the Dutch Copyright Act only permits the unauthorized use of sources that have already been lawfully made available to the public. ${ }^{100}$ Nonetheless, the Court of Appeals of The Hague ruled in favour of the journalist Karin Spaink in Scientology/Spaink. On an XS4All webpage, Spaink had posted parts of the so-called "Fishman Affidavit" - a semi-secret written declaration that had been submitted in other court proceedings initiated by Scientology against Steven Fishman. Spaink used quotations from confidential parts of the Fishman Affidavit reflecting the teachings and organization of Scientology to undergird her critique of Scientology. ${ }^{101}$ As the document had never been published lawfully, the statutory right of quotation was unavailable as a defence. ${ }^{102}$ However, Spaink successfully argued for direct application of the fundamental guarantee of freedom of expression and information in Art. 10 of the European Convention on Human Rights. The Court of Appeals of The Hague agreed that the quotations contributed to a legitimate form of criticizing Scientology's questionable ideas and behaviour. In the opinion of the Court of Appeals, Spaink's use of the documents did not amount to copyright infringement against this background. ${ }^{103}$ In the light of Pelham, however, the Scientology/Spaink decision of the Court of Appeals turns out to be incompatible with EU law. ${ }^{104}$ Invoking the freedom of the press, the Court of Appeals neglected the requirement of an earlier lawful act of making available to the public and failed to keep within the harmonized legal framework for copyright. ${ }^{105}$

Luckily, the CJEU changes its course from time to time. It cannot be ruled out that the Court - confronted with a Scientology/Spaink scenario - will finally realize that the invocation of fundamental rights as external correction tools is sometimes indispensable to strike a proper balance and permit the unauthorized use of protected material outside the statutory copyright framework. ${ }^{106}$ If the CJEU

\footnotetext{
98 For a more consistent and more flexible approach, see Aplin and Bently (2020).

99 Cf. de Zwaan (2012), p. 141; Senftleben (2013b), p. 3.

100 For a more detailed discussion of the Dutch regulation of quotations, see Senftleben (2012), p. 359 (359-412). The requirement of lawful prior making available to the public can also be found at the international level. See Art. 10(1) BC.

101 Court of Appeals of The Hague, 4 September 2003, Scientology/Spaink, Tijdschrift voor auteurs-, media- en informatierecht 2003, 217, para. 2.

102 Court of Appeals of The Hague, ibid., para. 7.11.

103 Court of Appeals of The Hague, ibid., paras. 8.2 and 13. Cf. Senftleben (2012), p. 359 (372-373).

104 Kulk and Teunissen (2019b), p. 149 (153).

105 Court of Appeals of The Hague, ibid., paras. 8.2 and 13.

106 Cf. Kulk and Teunissen (2019a), p. 121 (130-132); Snijders and van Deursen (2019), p. 1176 (1186-1187); Geiger and Izyumenko (2019), p. 131 (131); Griffiths (2019), p. 35 (46-49). This approach would also comply with the case law of the European Court of Human Rights, 10 January 2013, case 36769/08, Ashby Donald/Frankrijk, para. 38.
} 
upholds the mantra of complete and closed regulation of exclusive rights and limitations in a Scientology/Spaink scenario, inroads into freedom of expression and freedom of the press seem inescapable. Takings from unpublished sources will inevitably fall outside the scope of Art. 5(3)(d) ISD - regardless of their importance to the debate and the need to inform the public. In Funke Medien NRW, the Court already came within a hair's breadth of this dilemma. The case concerned the "Afghanistan papers": military status reports on the deployment of German armed forces. ${ }^{107}$ Given the confidentiality of these documents, German courts had denied the right of quotation because the requirement of prior lawful making available was not fulfilled. ${ }^{108}$ Not surprisingly, the prejudicial questions raised the issue of an extensive interpretation of the right of quotation in the light of freedom of expression and freedom of the press. The CJEU managed to bypass this delicate issue by following an alternative path and adopting a flexible interpretation of the concept of "reporting of current events" which is central to one of the press privileges laid down in Art. 5(3)(c) ISD. As Funke Medien had presented the Afghanistan papers on its website "in a structured form in conjunction with an introductory note, further links and a space for comments", ${ }^{109}$ the Court was satisfied that the online publication could be qualified as a privileged form of "use of works ... in connection with ... reporting". ${ }^{110}$ In this way, the Court paved the way for the application of Art. 5(3)(d) ISD and concealed the dilemma arising from the requirement of a lawful prior making available in Art. 5(3)(d) ISD. ${ }^{111}$ Moreover, this strategy allowed the Court to maintain the rule that copyright had to be reconciled with freedom of expression and freedom of the press within the system of rights and limitations in EU copyright law. ${ }^{112}$

\section{Conclusion}

In sum, the Pelham decision of the CJEU yields mixed results. There is light and shadow. As the Court confirms its commitment to a fair balance between the rights of authors and users in the copyright arena, the judgment gives hope that, when confronted with a problem scenario, the CJEU will eventually come up with a pragmatic solution. ${ }^{113}$ The decision in Funke Medien NRW shows that a broad interpretation of limitation prototypes in Art. 5 ISD may offer such a solution. ${ }^{114}$ Unfortunately, however, it becomes harder and harder to predict the Court's

\footnotetext{
107 CJEU, 29 July 2019, case C-469/17, Funke Medien NRW, para. 9.

108 German Federal Court of Justice, 1 June 2017, case I ZR 139/15, Afghanistan Papiere, GRUR 2017, 901, paras. 27-30.

${ }^{109}$ CJEU, 29 July 2019, case C-469/17, Funke Medien NRW, para. 75.

110 CJEU, ibid., para. 75.

111 CJEU, ibid., para. 75.

112 CJEU, ibid., para. 58.

${ }^{113}$ Kulk and Teunissen (2019a), p. 121 (123).

114 Cf. Kulk and Teunissen (2019b), p. 149 (156-157, 160); Snijders and van Deursen (2019), p. 1176 (1186-1187).
} 
ingenious solutions. Without a green light for the use of fundamental rights as balancing instruments that allow judges to go beyond the encrusted copyright framework at EU level, chances are high that national courts will readily qualify forms of use as infringing, even though a source of flexibility may lie hidden somewhere in the copyright acquis which the CJEU has not identified yet.

Again: the criterion of unrecognizability may provide a solution in cases of collage sampling. An elastic approach to the dialogue requirement may offer additional breathing space for the use of recognizable sound samples under the umbrella of the right of quotation. Apart from these tailor-made solutions for sound sampling cases, however, the Pelham decision fails to offer guidance for the solution of adaptation scenarios without encroachments upon freedom of the arts, freedom of expression and freedom of information. The CJEU could have prevented this unsatisfactory outcome and legal uncertainty by declaring adaptations permissible if the secondary author has added a sufficient degree of own originality to make protected features of reproduced source material fade away. This more flexible assessment standard would have safeguarded national doctrines that have evolved in EU Member States, such as the German doctrine of "freie Benutzung". Moreover, the CJEU could have provided universal guidance for adaptation scenarios - guidelines that avoid the risk of corrosive partial reproduction nitpicking and, instead, encourage an overall assessment of creative input leading to a derivative work, including free, creative choices of the secondary author. From this perspective, the Pelham judgment is a lost opportunity to develop EU copyright and neighbouring rights law in the light of the national legal traditions of EU Member States.

Open Access This article is licensed under a Creative Commons Attribution 4.0 International License, which permits use, sharing, adaptation, distribution and reproduction in any medium or format, as long as you give appropriate credit to the original author(s) and the source, provide a link to the Creative Commons licence, and indicate if changes were made. The images or other third party material in this article are included in the article's Creative Commons licence, unless indicated otherwise in a credit line to the material. If material is not included in the article's Creative Commons licence and your intended use is not permitted by statutory regulation or exceeds the permitted use, you will need to obtain permission directly from the copyright holder. To view a copy of this licence, visit http:// creativecommons.org/licenses/by/4.0/.

\section{References}

Alberdingk Thijm CA (1998a) Fair use: het auteursrechtelijk evenwicht hersteld. Tijdschrift voor auteurs, media- en informatierecht 1998:145

Alberdingk Thijm CA (1998b) Fair use - in weiter Ferne, so nah. Tijdschrift voor auteurs-, media- en informatirecht 1998:176

Aplin T, Bently L (2020) Displacing the dominance of the three-step test: the role of global, mandatory fair use. In: $\mathrm{Ng} \mathrm{L}$, Sun $\mathrm{H}$, Balganesh S (eds) Comparative aspects of limitations and exceptions in copyright law. Cambridge University Press, Cambridge

Bently L, Dusollier S, Geiger C et al (2019) Sound sampling, a permitted use under EU copyright law? Opinion of the European Copyright Society in relation to the pending reference before the CJEU in case C-476/17, Pelham GmbH v. Hütter. Int Rev Intell Prop Compet Law 50:467

Cohen Jehoram H (1998) Fair use - die ferne Geliebte. Tijdschrift voor auteurs-, media- en informatierecht 1998:174 
Cohen Jehoram H (2005a) Nu de gevolgen van trouw en ontrouw aan de Auteursrechtrichtlijn voor fair use, tijdelijke reproductie en driestappentoets. Tijdschrift voor auteurs-, media- en informatierecht 2005:153

Cohen Jehoram H (2005b) Restrictions on copyright and their abuse. Eur Intell Prop Rev 2005:359

de Zwaan M (2012) Ruimte in het citaatrecht in Europa? Zoekmachine vindt niets bij "search naar flexibilities". Tijdschrift voor auteurs-, media- en informatierecht 2012:141

Dreier T (2001) Balancing proprietary and public domain interests: inside or outside of proprietary rights? In: Dreyfuss RC, Leenheer-Zimmerman D, First H (eds) Expanding the boundaries of intellectual property. Innovation policy for the knowledge economy. Oxford University Press, Oxford, p 295

Dreier T, Schulze G (2018) Urheberrechtsgesetz, 6th edn. C.H. Beck, Munich

Duhanic I (2016) Copy this sound! The cultural importance of sampling for hip hop music in copyright law - a copyright law analysis of the sampling decision of the German Federal Constitutional Court. Gewerblicher Rechtsschutz und Urheberrecht - Internationaler Teil 2016:1007

Förster A (2008) Fair use. Mohr Siebeck, Tübingen

Geiger C, Izyumenko E (2014) Copyright on the human rights' trial: redefining the boundaries of exclusivity through freedom of expression. Int Rev Intell Prop Compet Law 45:316

Geiger C, Izyumenko E (2019) Freedom of expression as an external limitation to copyright law in the EU: the Advocate General of the CJEU shows the way. Eur Intell Prop Rev 41:131

Geiger C, Izyumenko E (2020) The constitutionalization of intellectual property law in the EU and the Funke Medien, Pelham and Spiegel Online decisions of the CJEU: progress, but still some way to go! Int Rev Intell Prop Compet Law 51 (forthcoming)

Geller PE (2010) A German approach to fair use: test cases for TRIPs criteria for copyright limitations? J Copyright Soc USA 57:901

Gervais D, Derclaye E (2012) The scope of computer program protection after SAS: are we closer to answers? Eur Intell Prop Rev 2012:570

Griffiths J (2014) The role of the Court of Justice in the development of European Union copyright law. In: Stamatoudi A, Torremans P (eds) EU copyright law. A commentary. Edward Elgar, Cheltenham, p 1106

Griffiths J (2019) European Union copyright law and the Charter of Fundamental Rights - Advocate General Szpunar's opinions in (C-469/17) Funke Medien, (C-476/17) Pelham GmbH and (C-516/ 17) Spiegel Online. ERA Forum 2019:35

Hugenholtz PB (1989) Auteursrecht op informatie. Kluwer, Deventer

Hugenholtz PB (2013) Comment on the judgement of the Court of Justice of the European Union, 15 March 2012, case C-135/10. SCF/Marco del Corso. Nederlandse Jurisprudentie 2013:197

Hugenholtz PB, Senftleben MRF (2011) Fair use in Europe. In search of flexibilities. IViR/VU Centre for Law and Governance, Amsterdam

Kulk S, Teunissen P (2019a) Naar een nieuw fundament - hoe het Handvest het auteursrecht hervormt (deel 1). Tijdschrift voor auteurs-, media- en informatierecht 2019:121

Kulk S, Teunissen P (2019b) Naar een nieuw fundament - hoe het Handvest het auteursrecht hervormt (deel 2). Tijdschrift voor auteurs-, media- en informatierecht 2019:149

Kur A (2014) Trademarks function, don't they? Int Rev Intell Prop Compet Law 45:434

Leistner M (2019) Ende gut, alles gut ... oder "Vorhang zu und alle Fragen offen"? Das salomonische Urteil des EuGH in Sachen "Pelham" [Metall auf Metall]. Gewerblicher Rechtsschutz und Urheberrecht 2019:1008

Morrison DM (2008) Bridgeport redux: digital sampling and audience recoding. Fordham Intell Prop Med Entertain Law J 19:75

Ohly A (2017) Hip Hop und die Zukunft der "freien Benutzung" im EU-Urheberrecht - Anmerkungen zum Vorlagebeschluss des BGH "Metall auf Metall III". Gewerblicher Rechtsschutz und Urheberrecht 2017:964

Podszun R (2016) Postmoderne Kreativität im Konflikt mit dem Urheberrechtsgesetz und die Annäherung an "fair use". Zeitschrift für Urheber- und Medienrecht 2016:606

Ricketson S, Ginsburg JC (2006) International copyright and neighbouring rights, 2nd edn. Oxford University Press, Oxford

Schipper BHM (2014) Het chilling effect van Kraftwerk I/II op sound sampling. Tijdschrift voor auteurs-, media- en informatierecht 2014:105

Schipper BHM (2019) De kunst van het samplen na Pelham. Tijdschrift voor auteurs-, media- en informatierecht 2019:162 
Senftleben MRF (2010) The international three-step test - a model provision for EC fair use legislation. J Intell Prop Inf Technol E-Commer Law 2010:67

Senftleben MRF (2012) Quotations, parody and fair use. In: Hugenholtz PB, Quaedvlieg AA, Visser DJG (eds) A century of Dutch copyright law - Auteurswet 1912-2012. DeLex, Amstelveen, p 359

Senftleben MRF (2013a) Comparative approaches to fair use: an important impulse for reforms in EU copyright law. In: Dinwoodie GB (ed) Methods and perspectives in intellectual property. Edward Elgar, Cheltenham, p 30

Senftleben MRF (2013b) Internet search results - a permissible quotation? Revue internationale du droit d'auteur 2013:3

Senftleben MRF (2016) Trademark transactions in EU law: refining the approach to selective distribution networks and national unfair competition law. In: de Werra J, Calboli I (eds) The law and practice of trademark transactions - a global and local outlook. Edward Elgar, Cheltenham, p 327

Snijders T, van Deursen S (2019) The road not taken - the CJEU sheds light on the role of fundamental rights in the European copyright framework - a case note on the Pelham, Spiegel Online and Funke Medien decisions. Int Rev Intell Prop Compet Law 50:1176

Spoor JH, Verkade DWF, Visser DJG (2019) Auteursrecht, 4th edn. Wolters Kluwer, Deventer

van Eechoud MMM (2011) Comment on the judgment of the Court of Justice of the European Union, 1 December 2011, case C-145/10, Painer. Tijdschrift voor auteurs-, media en informatierecht 2011:6

Visser DJG (2013) Openbaar maken met ketchup. Tijdschrift voor auteurs-, media- en informatierecht 2013:41

Publisher's Note Springer Nature remains neutral with regard to jurisdictional claims in published maps and institutional affiliations. 